\title{
ARCHAEOLOGY, MATERIAL CULTURE, AND SOCIAL INCLUSION IN BRAZIL
}

\author{
Arqueologia, cultura material e \\ inclusão social no Brasil
}

\author{
Pedro Paulo A. Funari* \\ Renata S. Garraffoni** \\ Maria Aparecida de Almeida*
}

\begin{abstract}
Heritage is a most controversial subject. It may be considered a way of upholding received wisdom and traditional mores, but it may also be considered a potent way of challenging established ideas and practices and fostering critical thinking and action. It all depends on the stand we take about heritage. The aim of this paper is to discuss the second perspective: the authors focus on three case studies in Brazil to argue that material culture, when understood in a progressive way, can promote social inclusion and community empowerment.
\end{abstract}

Keywords: Public archaeology, heritage, social inclusion

\section{RÉSUMÉ}

Le patrimoine est un sujet complexe. Il peut être considéré comme un moyen de transmettre des savoirs ou connaissances morales, tout comme il peut se révéler être un instrument de premier plan pour remettre en cause des pratiques et des idées toutes faites, générant dans le même temps une action et une pensée critique. Tout dépend de la manière dont on aborde le patrimoine. L'objectif principal de cet article est justement

\footnotetext{
* History Department, Campinas State University, Brazil. E-mail: ppfunari@uol.com.br
** History Department, Federal University of Paraná, Brazil. E-mail: resenna93@gmail.com

*** Campinas State University, Brazil. E-mail: mcidalmeida@hotmail.com
} 
d'aborder cette question de diversité d'approches, en étudiant les significations de la seconde perspective sur le patrimoine : les auteurs y discutent trois études de cas au Brésil pour soutenir l'idée que la culture matérielle, quand elle est pensée de manière progressive, peut promouvoir l'inclusion sociale et l'empowerment.

Mots-clés: archéologie publique, patrimoine, inclusion sociale

\begin{abstract}
RESUMO
Patrimônio é um tema complexo. Pode ser considerado uma maneira de transmitir sabedorias ou ensimanento morais, mas também pode se tornar instrumento importante para desafiar ideias e práticas estabelecidas, provocando o pensamento crítico e a ação. Tudo depende de como entedemos o que é patrimônio. $\mathrm{O}$ objetivo central desse artigo é discutir exatamente essa questão, explorando os significados dessa segunda perspectiva: os autores discutirão três estudos de caso no Brasil para arugumentar que cultura material, quando entendida de maneira mais progressiva, pode promover inclusão social e empoderamento.
\end{abstract}

Palavras-chave: Arqueologia pública, patrimônio, inclusão social

\title{
Introduction
}

The notion that the past needs to be conserved for the benefit of future generations is well known in different disciplines, such as archaeology or heritage management. As a result, traditionally, cultural heritage - tangible or intangible - was considered a source of national or ethnic identity and social cohesion. Archaeology and heritage thus were often used for the purposes of conserving the status quo. A glimpse at pictures of Napoleon's expedition to Egypt convinces us that archaeology started as a military endeavour linked to nationalism and imperialism, as was proposed by the Canadian archaeologist Bruce G. Trigger (1984) more than three decades ago. What a contrast to compare those images with recent ones, showing hands-on archaeological activities and community involvement in Brazil. In Brazil, archaeology serves as a tool for social inclusion, enlightenment, and critical thinking and practices. Archaeology and heritage studies have thus come a long way, from conservatism and 
social exclusion to more inclusive and democratic practices and perspectives. We interpret modern history, and consequently archaeology, in a progressive way, from nationalism and imperialism to social inclusion and democracy, even if we do not shy away from the contradictions and perils inherent in modernity as destruction (GONZALES-RUIBAL 2008) and narrow-minded nationalism and xenophobia. These are important issues and we are also uncertain about what the futre will bring. However, we consider that the past 200 years in general, and the most recent decades in particular, witnessed a growing awareness of diversity and justice as key values (FUNARI 2009; LITTLE 2009). Women's and feminist perspectives, for instance, are particularly meaningful in challenging social relations and scholarly practices, as is a historical approach.

In this paper, ${ }^{1}$ we argue that recognizing present challenges, especially the rights of communities to manage their cultural properties and create their own narratives of the past, can be important tools for local empowerment and new narratives of the past. Worldwide, archaeology has contributed to new practices, particularly since the establishment of the World Archaeological Congress in 1986, when indigenous peoples, ordinary citizens, and scholars from different backgrounds began interacting more regularly. Brazil has been a very active participant in this innovative approach, at least in part because the concept of learning with the people was fostered by the Brazilian education scholar and practitioner Paulo Freire (1967; 1996). Our case studies deal with two institutions in Brazil, involved in two projects: one in Campinas (southeastern Brazil) and the other in Curitiba (southern Brazil). Both of them deal with archaeology, material culture, and heritage in a progressive way, aiming at social inclusion and the education of citizens who are critical and open to diversity and respect for differences.

1 Parts of this paper were originally presented at the 2016 conference of the Association of Critical Heritage Studies, held in Montréal, Canada. In light of the new partnership between the Museo Paranaense and Universidade Federal do Paraná, established in 2017, we have updated some of the information and analysis presented at the conference. 


\section{A Historical Approach and the Brazilian Context}

According to Bruce Trigger, "A historical approach offers a special vantage point from which the changing relations between archaeological interpretation and its social and cultural milieu can be examined" (1990: 4). In this section, we will situate the context of archaeology in Brazil.

Brazil is a huge country, with an area of $8,514,877 \mathrm{~km}^{2}$, twice that of the European Union $\left(4,324,782 \mathrm{~km}^{2}\right)$. It has a population of more than 190 million and a GDP of $\$ 2.493$ trillion USD. The number of practising archaeologists is difficult to establish, but whereas it was a few hundred 20 years ago, the number is now probably in the thousands, with most of them working in cultural resource management (SCHAAN \& BEZERRA DE ALMEIDA, 2009).

Funari and Garraffoni (2016: 282-286) have recently pointed out that archaeology started earlier in Brazil than it did in most parts of Latin America. The Portuguese crown decided to move the capital of colonial power from Lisbon to Rio de Janeiro in 1808. When the Portuguese regent, the future Pedro I declared Brazil independent from Portugal in 1822, he also established Brazilian archaeology, importing archaeological artifacts from other countries, such as Egyptian mummies (FUNARI \& FUNARI, 2010). Archaeology flourished in the independent colony, the Empire of Brazil (18221889), under the rule of Pedro I and his son, Pedro II. It is important to emphasize that the imperial thrust was followed by a deep horror indigenae - indigenous people had a minor role to play in the early nationalistic politics, relegating archaeology to a most humble endeavour. In the 1930s, nationalism gave a new impetus to history and heritage: the colonial ideal and the indigenous past became relevant and served to build the nation. The colonial period (ending in 1889) became the main period to define Brazilian society, particularly during the fascist New State dictatorship period (1937-1945), and archaeology, as a scholarly endeavour, started during this period as a reaction against this move (FUNARI, 1999).

Paulo Duarte (1899-1984) was a key figure (FUNARI \& SILVA, 2007) as a democratic political activist during the later years 
of the oligarchic republic, when he contributed to the founding of the first Brazilian university, the University of São Paulo (1934), modelled on a humanist approach to scholarship. But Duarte did not tolerate the country's dictatorial rule (1937-1945), preferring exile. During this period, his humanist ideals led him to American and French anthropology and to the struggle for human rights, particularly those of indigenous peoples. The Musée de l'Homme in Paris served as the model for considering indigenous peoples to be of equal importance to any other humans. Upon returning to Brazil, Duarte spearheaded a movement for Amerindian rights; as a consequence, prehistoric and humanist archaeology flourished during the liberal period (1945-1964). Thanks to his efforts and to allies engaged in similar pursuits, the Brazilian Congress approved the first and only law protecting archaeological remains, in 1961. However, the country would suffer under military rule for 21 long years (1964-1985), and humanism, prehistory, and archaeology were direly affected. Soon after the military coup, a national archaeological study program, titled Programa Nacional de Pesquisas Arqueológicas (Pronapa), was set up to initiate an archaeological survey across the country. The survey focused on militarily strategic areas and contributed to the effort to maintain Brazilian sovereignty during the Cold War. The empirical and theoretical tenets of ProNaPA were highly reactionary and antihumanist, promoting the concept that native peoples were lazy and were responsible, in part, for the poor economic conditions of the country (NOELLI \& FERREIRA, 2007). The survey commenced in 1965, and it moved to the Amazon basin in 1970, when guerillas were fighting against the dictatorship. During the long dictatorial rule, which hindered freedom and humanism, a network of archaeologists brought up in those dire circumstances shaped the practice of archaeology. The country also faced a wave of persecution, exile, killing, and missing people (FUNARI, 1994).

The restoration of civilian rule (1985), the new constitution (1988), and the transfer of power to states and municipalities led to new developments in academia in general and had a positive influence on archaeology. The new democratic constitution established a series of general principles related to environmental and heritage protection and thus concerned archaeology in new and revolutionary ways. Consequently, archaeology is now a practice 
reaching all 27 states and the Federal District of the Union, and it is a highly popular endeavour, as attested by its presence in a number of publications available in newsstands all over the country.

This leads us to public archaeology, a relatively recent field in the discipline worldwide, but one in which Brazil has been at the forefront (FUNARI \& BEZERRA, 2012). Public archaeology is the direct result of awareness of the political character of the discipline. It has been shown that archaeology is as much the study of power as it is the study of the past, as stressed by Michael Shanks and Christopher Tilley (1987). This reversal of meaning of the discipline has caused a sea change: from the study of the past to the study of the present, from remembrance to reenactment. It is beyond dispute that archaeology has been a dream-driven endeavour from the start, a unique way of voyaging in time and in space, and this is still the most enticing aspect of the discipline. The practice of public archaeology is thus a consequence of the realization by scholars that scholarly disciplines, including archaeology, are relevant to the present and to contemporary social issues. Public archaeology has been a growing pursuit worldwide since the 1990s, and it has developed quickly in Brazil in the past few years. School kids, the wider adult population, maroon populations, and indigenous populations have not just been put into contact with archaeology, but have helped forge the discipline itself.

The interaction of archaeologists with ordinary people aims at producing scholarship relevant to society at large as well as specific groups. Brazil, along with other countries in Latin America, such as, notably, Cuba, Mexico, and Colombia, is characterized by its cultural diversity, comprising indigenous peoples; European colonists of a variety of origins; peoples of African descent; as well as populations from Japan, China, the Middle East, and beyond. Every human society is multiethnic and mixed, but Latin American ones are particularly so, and the Brazilian one no less than any other. One of the results of this is the fact that, considering their variety, interaction with the people may prove epistemologically enriching. This was the stand spearheaded by Paulo Freire, so that learning with the common people was understood as being important for scholarship. Brazilian archaeology has used this epistemological position in its development of public archaeology (BEZERRA, 2012; EREMITES DE 
OLIVEIRA, 2005; FUNARI et al., 2007; GREEN et al., 2010; OLIVEIRA and FUNARI, 2011).

\section{Social Inclusion through Archaeology}

As Little (2007) has already pointed out, the past is an important aspect of modern life. If what we learn from history can shape our lives, it is then urgent to discuss our attitudes towards the past. Little also argued that it is possible to use material culture as a glimpse into human history and as a tool to promote hope and thereby renew our present. It is important to discuss difficult or traumatic elements of the past as a way to promote social justice or engagement in a common struggle that reach different marginalized social groups. To discuss denied, hidden, or distorted pasts will not give us harmonious narratives, but it will give more realistic and worthwhile references for communities' lives. Little (2007: 136) also stated that public archaeology should include archaeologists' collaborations within communities to increase the sense of social responsibility beyond professional self-interest, to support social engagement, and to promote civic renewal. Although she refers to the American experience, this perspective can be an important means with which to think about social justice, Brazilian history and our difficult past. Brazilian public archaeology should be a powerful tool to express diversity and express the complexity of the past, which was denied or silenced during different authoritarian periods.

The case studies we shall focus on are examples of how public archaeology and engaged museology can play an important role for social and political empowerment, help us to construct new ways to learn from the past, and create more inclusive paths for the future. They also emphasize that interdisciplinarity and social responsibility are part of this process and that public discussion of how we commemorate the past allows us to create more positive contributions for future generations. To discuss those issues, we shall focus on case studies we have been working on for the past few years: 
the Laboratorio de Arqueología Pública/Public Archaeology Laboratory at a state university, the Universidade Estadual de Campinas (usually referred to as UNICAMP), and the partnership between a federal university, Universidade Federal do Paraná (usually referred to as UFPR), and a state museum, the Museo Paranaense.

\section{The Public Archaeology Laboratory}

At UNICAMP, located in southeastern Brazil, a social inclusion program has been created. The Public Archaeology Laboratory has been developing activities with high school students since 2013. Brazilian education is imbalanced, as most of the pupils go to free public schools, while the middle and upper echelons have access to a much better education by paying to attend private schools. To help remedy this appalling situation, UNICAMP has established several programs to foster social inclusion. Sometimes other scholarly agencies, such as the Brazilian science foundation, Conselho Nacional de Desenvolvimento Cientifico e Tecnologico (known by the acronym $\mathrm{CNPq}$ ), also support social inclusion programs. One of the programs, encourages the best pupils in free high schools in Campinas, a city with more than one million inhabitants, to participate in laboratories and research centers at the university (MORAES \& ALMEIDA, 2016).

The Public Archaeology Laboratory program encourages pupils to explore archaeology as a way of understanding the world in its materiality. This engagement also fosters a critical understanding of archaeology. The laboratory has also included those same pupils in another program, sponsored again by the Brazilian Science Foundation, to produce a booklet for children about archaeology, explaining its scope, subjects, and goals. This program produced an innovative book for children, which were then used in several schools in different states of the country. The booklet was published in paper in two editions and is available free of charge for download. ${ }^{2}$ Several

2 The authors may be contacted for a copy of this or it can be downloaded at the following address: https://www.academia.edu/28968822/Arqueologia_uma_atividade_divertida__Edi\%C3\%A7\%C3\%A3o_Zanettini_2016_e_Onze_mil_anos_em_S\%C3\%A3o_Manuel_-_Zanettini 
good references to activities in schools that involve use of the book attest to its success. ${ }^{3}$

The booklet, Arqueologia: uma atividade muito divertida (tr. archaeology: a fun activity), presents archaeology as the study of the material world, from the past to the present. It includes among its topics underwater sites, fieldwork, laboratory analysis and storage, museum exhibits, the first inhabitants of the country, extinct fauna, rock art, lithics, pottery, metallurgy, museums, maroons, and repression and resistance during dictatorships. It also addresses what to do when someone finds archaeological remains, how to study archaeology, and where do practice it, as well as the professional perspectives. It includes a word on three inspiring archaeologists and humanists: Vere Gordon Childe, Peter Ucko, and the Brazilian pioneer Paulo Duarte. The book concludes by inviting children to draw in the book itself inspired by what they read and did, as well as to participate in practice of archaeology.

It is worth mentioning that the volume mentions and encourage the participation of local communities, so that it presents archaeology as an activity for everybody in order to promote universal human values. The inclusion of a disabled person among the archaeologists signals that there are no barriers for those wishing to take part. Several of those features are new in Brazil, for there has a perception that archaeology is for a few people, possibly rich, and that it does not deal with issues that are relevant for society. The book teaches that rock art is not only beautiful, but also proof that indigenous peoples in what is now Brazil produced culture and that indigenous peoples are not barbarians. Exploitation, inequality, and the struggle against it is present in the archaeology of maroons and of repression and resistance. By including Childe, Ucko, and Duarte as role models, the book indicates that archaeologists may be interested in social justice, contrary to the common perception of them as imperialist agents and upper crust adventurers. This is particularly relevant in the Brazilian context of past use of archaeology for authoritarian and conservative tenets and practices. The laboratory

3 http://www.unicamp.br/unicamp/noticias/2014/10/21/lap-lanca-livro-infantil-abordandoarqueologia; http://www.unifal-mg.edu.br/comunicacao/projetoarqueologiaumaatividadedivertida 
focus is on an inclusive approach and promoting a critical dialogue between community and university.

Figure 1

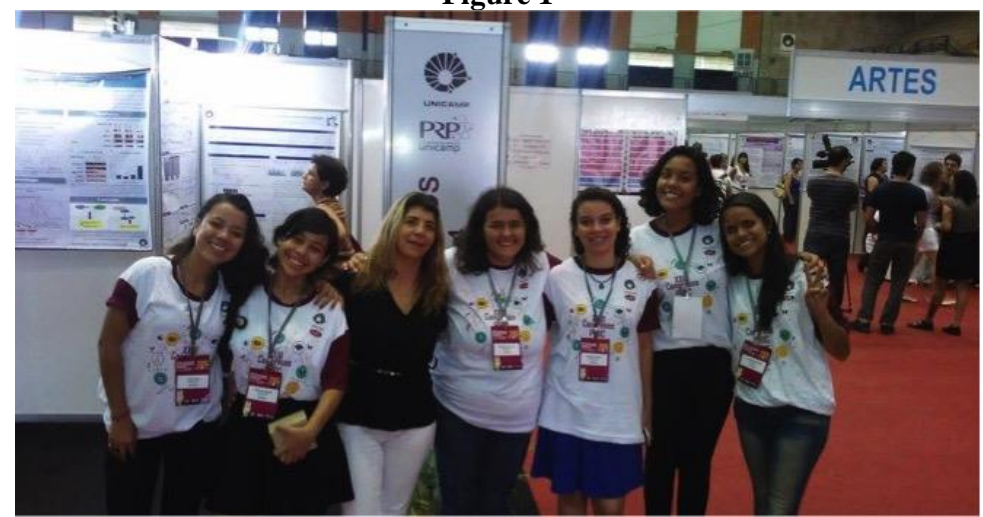

Dr. Maria Aparecida Almeida and pupils from public high schools at Campinas

Figure 2

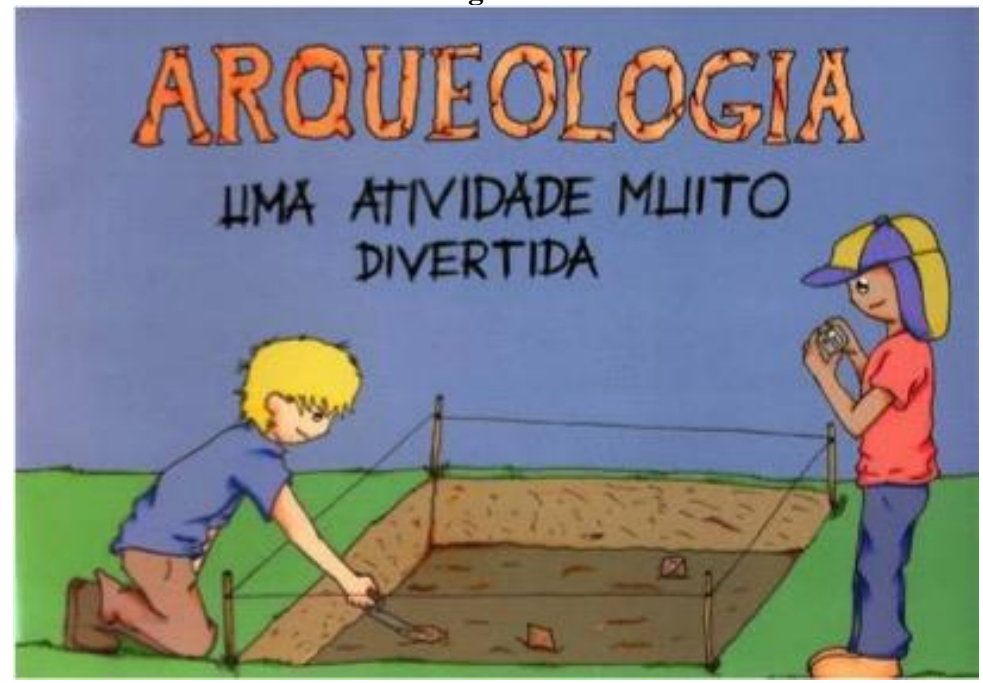

Booklet's cover

Figure 3 


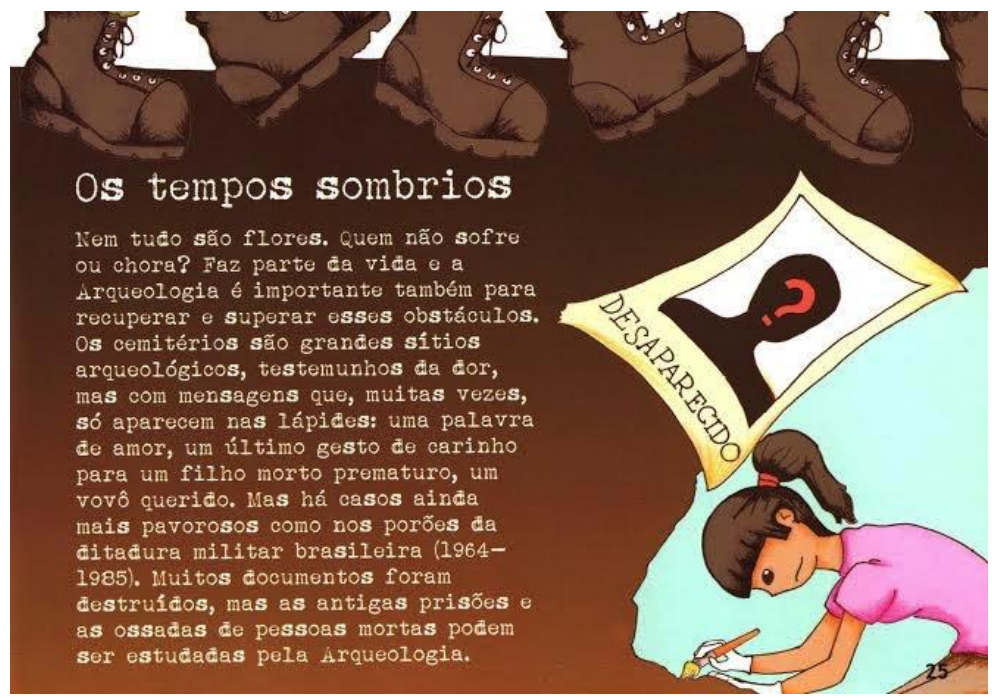

Booklet's page on repression and resistance during dictatorships

\section{The partnership between Universidade Federal do Paraná and Museu Paranaense}

Feminist theory can be a powerful tool to challenge archaeologists to confront silences and exclusions. As Gilchrist (1999) has stated, archaeology has experienced a paradigm shift resulting from feminism: feminism heightened concern for the lack of publications by women and promoted gendered (or gender-aware) approaches to material culture. Despite these historic changes, the state-owned Museo Paranaense presented a male-centered narrative and display; women were misrepresented. In 2013, when one of us (RG) was head of the Programa de Educação Tutorial (tr. program for tutorial education), which encourage high achievement among undergraduate students, ${ }^{4}$ she proposed to the museum's director, Renato Carneiro, Jr., a partnership involving the students of UFPR's Departamento de História, the Museo Paranaense, and the community 
to problematize the absence of women's history in the museum's exhibits.

Research was carried out over the course of 2014, and the students were encouraged to do research in the storage rooms, and they found a great diversity of material culture linked to elite women's daily lives - mainly clothes, shoes, hats, and bathing suits, but also baby clothes - from the end of the $19^{\text {th }}$ century to the early 1960. All items were well preserved and represented different moments in elite women's lives: marriage, parties, motherhood, the baptism of a baby, and death. Our study of those moments and their meanings involved locating some of the donors or their families and interviewing them to understand why they had decided to donate those items to a state museum. We also organized a workshop, to which we invited Maria Claudia Bonadio (Universidade Federal de Juiz de Fora), who studies fashion and gender; the donors; and members of the general public. The encounter raised conflicting ideas and prompted a spirited discussion on memory and heritage.

The workshop was a success, and the community became interested in the subject. Encouraged by this progress, the museum's director decided to open a new wing dedicated to the industries that were important for the development of Paraná State. Tatiana Takatuzi, head of the museum's department of history, considered the Venske factory to be a crucial element in the state's past and proposed it as a topic of research to the students. The Venske factory produced ribbon and textiles throughout the 20th century, and women composed a majority of the factory labour force (BOSCHILIA, 2010). Including Venske in the museum's main exhibit became a starting point to discuss gender, labour, class, fashion, women's rights, and women's struggles. This new exhibit also challenged the students to go back to the museum storage room with another perspective, and they found different photos and documents of those women's lives which contrasted to indigenous textiles and material culture held in the Museum. This research showed us the diversity of material culture relating to women's daily lives in the city and traditional communities and allowed us to discuss heritage, cultural diversity, memory, and display.

\section{Figure 4}




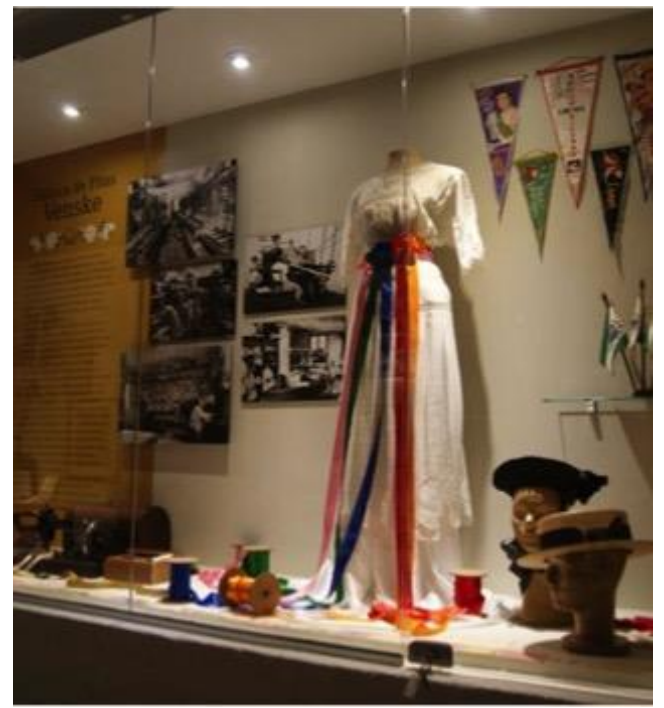

Museu Paranaense's main exhibition - the Venske factory

After this experience and community feedback, Garraffoni realized that the museum could be an important place to discuss gender inequality in both the present and the past. Therefore, she, together with Dr. Priscila Piazentini Vieira, proposed a wider research project titled Gênero e cultura material: A História das Mulheres no Museu Paranaense (Gender and Material Culture: The History of Women at Paranaense State Museum). This new project was approved by the Proec (University council for culture), and it began in March 2017. It is a two-year program and has two main aims: research and public debate. The research will be led by Garraffoni and Vieira and a group of students, who will organize and classify the artifacts on women's history in the museum's storage rooms. Three main subjects will be considered: women's labour, art (the museum has a huge collection of works by women painters and of women's portraits that have not yet been studied) and daily lives (clothing). Because neither scholars nor the community have any idea of the diversity of this material in the museum's storage rooms, the main 
goal of this new project is to share knowledge by organizing the material and publishing catalogues.

Regarding public debate, we have been promoting two different types of encounter. The one type has a more academic perspective. We invited colleagues to give talks on gender, feminism, memory, the history of women, and material culture for students and professors who had become interested in the project. These presentations were also an opportunity to engage the museum's staff with new approaches to the past; they could then use this information in the development of new exhibits. The other type of public debate is totally informal. We invited women from the community photographers, artists, activists, and women from social movements that fight for civil rights - to discuss the role of the museum in society to fight gender inequality and promote social inclusion. Those debates started in April 2017 and are planned to take place twice a month for the rest of the year. The informal debates are well attended, with more than 50 persons in each session. These debates will provide the basis for us to organize the new exhibit in a way that considers the community's point of view and provides new narratives of women's pasts. Considering initial results, especially the critical approach from women who are activist in black movement, it is possible to argue that a sizeable gap exists between the white male-centered exhibits and the people who visit the museum. This realization challenged us to develop new perspectives on conservation and heritage management. Public archaeology became an important tool to reconstruct the links with the community and develop a more pluralist approach to the past and to women's history.

\section{Discussion}

In the 1970s, the Peruvian archaeologist Luís Lumbreras argued that archaeology has played a reactionary role and been a tool for oppression (Lumbreras 1974). However, archaeology has also been a tool for social inclusion and liberation in the world in general, 
and in Latin America most of all. This means we should foster awareness of critical issues related to the way we study and commemorate the past. The development of the field of archaeology in Brazil, for instance, has been marked by a number of peculiarities: it initially developed during the imperial period, and over the course of the 20th century it underwent both humanist and authoritarian phases. One legacy, that of Paulo Duarte, who resisted academic and political persecution, has inspired generations of archaeologists since the end of the 20th century. With the democratic opening of Brazil that began in 1985, Duarte's intellectual legacy inspired new approaches. With the concurrent development of public and postprocessual Archaeology, the quest for more pluralist approaches to the past began to flourish throughout the nation. This development also promoted theoretical and methodological renewal, as well as increased public involvement.

The work targeting children and youth developed by the Public Archaeology Laboratory at the UNICAMP helps school children question the notion of archaeology as something pertaining to the world of adventure and the exotic and thereby enables them to understand the importance of material culture in constructing less normative notions of the past and a more pluralist present. The partnership between UFPR and Museo Paranaense shows how public archaeology is important for rethinking relations between an institution and a community and questioning memory and gender inequality. The experiences we have discussed here, albeit briefly, demonstrate how material culture is fundamental for empowerment, questioning the status quo, and aiding in the quest for more pluralist narratives of the past and, thereby, the construction of a more democratic and inclusive present. Our examples show that archaeological tools, both theoretical and methodological, are important for a more critical interpretation of the past. Multivocal history may not be harmonious, but debate is fundamental in order to build a different future. The initiatives of public archaeology illustrated by the case studies in this paper have thus been fostering social inclusion. The main goal is to promote justice and critical awareness (FUNARI, 2009). This is no simple task. 


\section{Acknowledgments}

The authors wish to thank all of the students in the Programa de Educação Tutorial program in history at UFPR who took part in the aforementioned activities in 2013 and 2014, as well as all of the students who were involved in the Public Archaeology Laboratory project. Furthermore, we are deeply grateful to the Museu Paranaense staff and to the following colleagues: Renato Carneiro Jr., Tatiana Takatuzi, Ana Paula Vosne Martins, Louise Alfonso, Lúcio Menezes Ferreira, Maria Claudia Bonadio, Tobias Vilhena de Moraes, Juliana Poloni, Denise Schaan, Elizabete Tamanini, Priscila Piazentini Vieira, Roseli Boschilia, and Paulo Zanetini. We also extend our thanks to the institutions that have made our projects possible: CNPq; Coordenação de Aperfeiçoamento de Pessoal de Nível Superior, Ministério da Educação; the São Paulo Research Foundation (known by the acronym FAPESP); Secretaria de Educação Superior, Ministério da Educação; UFPR; the Departamento de História, UNICAMP; and the Nucleo de Estudos de Gênero, UFPR. The authors are solely responsible for the ideas expressed in this paper.

\section{Bibliography}

Bezerra, M. Signifying Heritage in Amazon: A Public Archaeology Project at Vila De Joanes, Marajó Island, Brazil. Chungara : Revista de Antropología Chilena, vol. 44, n. 3, 2012, p. 533-542.

Boschilia, R.T. Entre fitas, bolachas e caixas de fósforos: a mulher no espaço fabril curitibano (1940-1960). Curitiba: Artes \& Textos. 2010.

EREMITES DE OLIVEIRA, J. Por uma Arqueologia socialmente engajada: Arqueologia Pública, universidade pública e cidadania. In : P. FUNARI, C. ORSER \& S. NUNES DE OLIVEIRA SCHIAVETTO (eds.). Identidades, discursos e poder: Estudos da 
Arqueología contemporânea. San Paulo: Fapesp/Annablume, 2005, p. 117-132.

FUNARI, P. P. A. \& BEZERRA, M. Public Archaeology in Latin America. In: R. SKEATES, C. MACDAVID \& J. CARMAN (eds.). The Oxford Handbook of Public Archaeology. Oxford: Oxford University Press, 2012, p. 100-115.

FUNARI, P. P. A. \& FUNARI, R. S. Ancient Egypt in Brazil: a theoretical approach to contemporary uses of the past. Archaeologies, vol. 6, 2010, p. 48-61.

FUNARI, P. P. A. \& GARRAFFONI, R.S. Arqueología participativa y empoderamiento comunitario en Brasil. Complutum, vol. 27, 2016, p. 281-294.

FUNARI, P. P. A. Paulo Duarte e o Instituto de Pré-História. Idéias. Campinas: Gráfica IFCH, vol.1, n.1, 1994, p. 155-179.

FUNARI, P. P. A. Brazilian archaeology: a reappraisal. In: G. POLITIS \& B. ALBERTI (eds.). Archaeology in Latin America. London: Routledge, 1999, p. 17-37.

FUNARI, P. P. A. Historical Archaeology and Global Justice. Historical Archaeology, vol. 43, 2009, p. 120-121.

FUNARI, P. P. A.; OLIVEIRA, N.V.; TAMANINI, E. Archaeology to the lay public in Brazil: three experiences. In: J.J. JAMESON, \& S. BAUGHER, (eds.). Past Meets Present: archaeologists partnering with museum curators, teachers, and community groups. New York: Springer, 2007, p. 217-228.

FUNARI, P. P. A. \& SILVA G. J. Nota de Pesquisa sobre o Projeto de Pesquisa do Acervo de Arqueologia e Patrimônio de Paulo Duarte 06/03/2007. História e-História, 2007, p. 1-25.

FUNARI, P. P. A. Historical Archaeology and Global Justice. Historical Archaeology, vol. 43, n. 4, 2009, p. 120-121.

FREIRE, P. Educação como prática da liberdade. São Paulo: Paz e Terra, 1967. 
FREIRE, P. Pedagogia da autonomia: saberes necessários à prática educativa. São Paulo: Paz e Terra, 1996.

GILCHRIST, R. Gender and Archaeology: Contesting the Past. London: Routledge, 1999.

GONZÁLEZ-RUIBAL, A. Time to Destroy: An Archaeology of Supermodernity. Current Anthropology, vol. 49, n. 2, 2008, p. 247279.

GREEN, L. F., GREEN, D. R. \& NEVES, E. G. Indigenous knowledge and archaeological science. Journal of Social Archaeology, vol. 3, n. 3, 2003, p. 366-398.

LITTLE, B. J. Why the past matters, Walnut Creek: Left Coast Press. 2007.

LITTLE, B. J. What Can Archaeology Do for Justice, Peace, Community, and the Earth? Historical Archaeology, vol. 43, n. 4, 2009, p. 115-119.

LUMBRERAS, L. La Arqueología como ciencia social. Lima: Histar, 1974.

MORAES, T. V. \& M. A. A. ALMEIDA. PIBIC-EM no núcleo de História e Arqueologia da Unicamp. Revista de Arqueologia Pública, vol. 10, n.2 (16), 2016, p. 60-68.

NOELLI, F. S. \& L.M.A. FERREIRA. A persistência da teoria da degeneração indígena e do colonialismo nos fundamentos da arqueologia brasileira. História, Ciências, Saúde-Manguinhos, vol. 14, 2007, p. 1239-1264.

OLIVEIRA, N.V., P.P.A. FUNARI \& L. CHAMORRO. Arqueologia Participativa: uma experiência com indígenas guaranis. Arqueologia pública, vol. 4, 2011, p.13-19.

SCHAAN, D. \& M. BEZERRA (eds.). Construindo a Arqueologia no Brasil: a trajetória de Sociedade de Arqueologia Brasileira. Belém: Sociedade de Arqueologia Brasileira-GK Noronha, 2009.

SHANKS, M. \& C. TILLEY. Reconstructing Archaeology: Theory and Practice. Cambridge: Cambridge University Press, 1987. 
TRIGGER, B. G. Alternative Archaeologies: Nationalist, Colonialist, Imperialist. Man, New Series, vol. 19, no. 3, 1984, p. 355-370.

TRIGGER, B. G. A History of Archaeological Thought. Cambridge: Cambridge University Press, 1990.

RECEBIDO EM: 01/06/2018 APROVADO EM: 12/07/2018 